\title{
Municipal Building Regulations for Energy Efficiency in Southern Italy
}

\author{
Eleonora Riva Sanseverino ${ }^{1}$, Raffaella Riva Sanseverino ${ }^{2}$, \\ Gianluca Scaccianoce ${ }^{1}$, and ValentinaVaccaro ${ }^{1}$ \\ ${ }^{1}$ University of Palermo, Department of Energy, \\ Information Enginering and Mathematical Models, DEIM, Palermo, Italy \\ \{eleonora.rivasanseverino, gianluca.scaccianoce\} @unipa.it, \\ valentina.vaccaro.pa@gmail.com \\ ${ }^{2}$ University of Palermo, Department of Architecture, DARCH, Palermo, Italy \\ raffaella.rivasanseverino@gmail.com
}

\begin{abstract}
The building sector is still one of the most energy consuming sectors in Italy, like developed countries in Europe. At European level, the main policy driver related to the energy use in buildings is the Energy Performance of Buildings Directive (EPBD, 2002/91/EC) and its recast. Through the EPBD introduction, requirements for certification, inspections, training or renovation are now imposed in Member States. In order to fulfill the expected changes, local regulations are a key factor aiming at sustainable territorial planning. It is thus required support the issue of local rules at municipal level in order to guide local administrators and technicians and to limit discretional power of bureaucracy. In this paper, a review of the most common practices for building regulations in Europe and in Italy is proposed, then the role and the framework of a municipal building regulation for the Southern European area accounting for sustainability features is discussed.
\end{abstract}

Keywords: Sustainable urban planning, Energy efficiency in buildings, Municipal building regulation.

\section{$1 \quad$ Energy Efficiency in Buildings and Relevant Regulations in Italy}

In Italy, the building sector is responsible for about $45 \%$ of primary energy consumption due to building materials and to the final use of energy from tertiary and residential buildings.

The data published from ENEA, in the annual report on energy efficiency (RAEE 2011) [1], show the incidence, in terms of primary energy consumption at national level, of the residential and no residential sector.

From the analysis of the use of energy in the residential sector, which is the one that mostly influence consumptions, emerges that heating (essentially based on natural gas) in 2010 covers more than two-thirds of the overall consumption (it was $68 \%$ of overall consumption in 2010), while hot water production and cooking 
respectively cover $9 \%$ and $6 \%$, while $17 \%$ is devoted to the electrical energy consumptions like lighting, appliances and air conditioning.

In Italy the total energy consumption per household is decreased of 8,3\% in 2010 as compared to 2000 (as an effect of the economic crisis in Italy), although the reduction is however lower as compared to the overall reduction across EU, since for EU-27 the average reduction is of 15,5\%, as confirmed by Figure1.

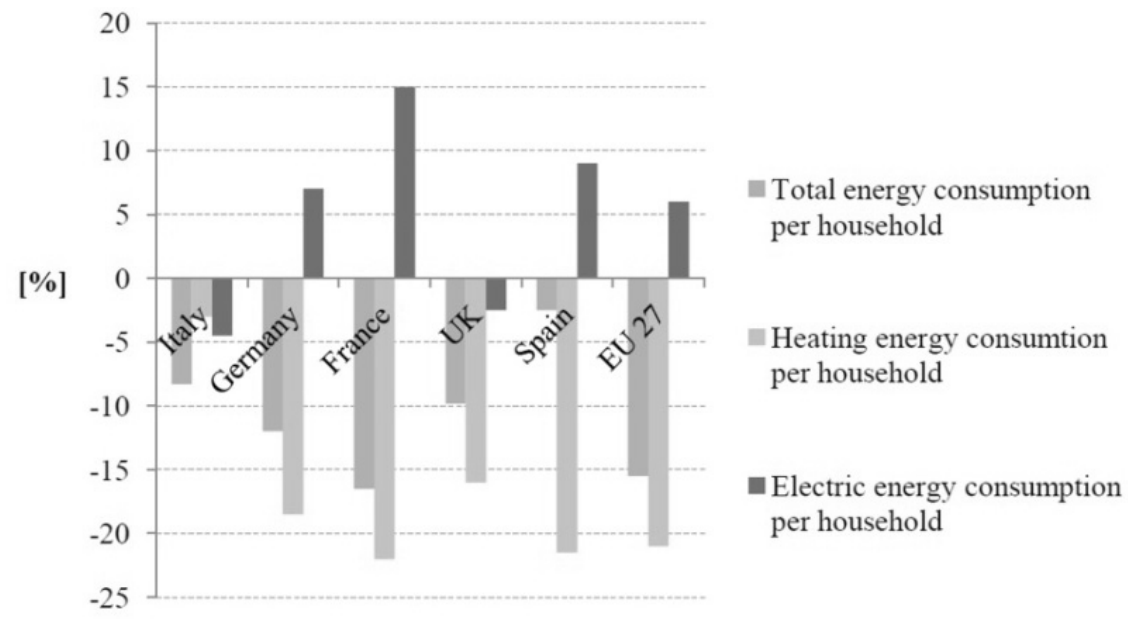

Fig. 1. Percentage variation of total electric and thermal energy consumption per household between 2000 and 2010 (Source: [1])

Essentially the electrical and thermal energy consumption determine the final level of energy efficiency in the residential sector, and, as evidenced from figure 1, the reduction of energy consumption in Italy is not large in the last 10 years and is mostly due to the economic crisis. Such element confirms that the energy efficiency actions in the buildings sector are not widespread in Italy. It is well-known that the policy orientations of EU strongly address towards sustainability in cities, buildings and technical infrastructures. At the European level, the main policy driver connected to energy use in buildings is the Energy Performance of Buildings Directive (EPBD, 2002/91/EC). Implemented in 2002, the EPBD Directive has been recast in 2010 (EPBD recast, 2010/31/EU) with more ambitious provisions.

Reaching objectives like the energy consuming reduction in buildings (Directive 2010/31/UE 'Energy efficiency in buildings', introduces the concept of near zero energy buildings), the rational use of energy, the integration of Renewable Energy Sources based production in buildings, etc. are the policy drivers in the member states and have a natural transposition in national laws and local regulations, with a different degree of detail according to the geographical scale to which they refer (provincial, town, etc.).

The European Commission considers local building regulations as a strategical element for the implementation of energy efficiency policies. A study commissioned by the EU in 2011 to the PRC Bouwcentrum International (Bodegraven, The Netherlands) in cooperation with Delft University of Technology (Delft, The 
Netherlands) [2], reports a screening of national building regulations ${ }^{1}$ in Europe. It analyzes whether and how the EU-27 member states currently regulate sustainable building. The report furthermore assesses whether and how these regulations are enforced on day to day basis. And finally assesses whether and how non-public market initiatives and public-private initiatives complement the formal building regulatory systems in addressing sustainability goals. Finally, the coherence and efficiency of the building regulatory systems are considered, and the possible needs for coordination at EU level to consolidate the regulatory framework are analyzed.

The study outlines the extreme diversity of local codes, moreover, although the interest in defining efficient regulations systems is quite high across UE, the approach it is very difficult to standardize .

The most utilized approach, in Europe, for regulations issueing in sustainable building practice is to introduce indications concerning the performances that the whole building or parts of it must have (performance-based approach). Rarely, in local building regulations, the installation of systems and technologies to improving the energy efficiency is considered mandatory. The latter features preserve the designers freedom of making their own design choices according to the most up to date technical rules and available commercial products, on the other hand, the administrations are burdened with checking the conformity of the energy efficiency measures with the requirements of the municipal building regulations. The latter is the main reason for which, some European countries, from a performance-based approach adopted a mixed performance-based/prescriptive approach, in which numerical and quantifiable parameters also expressing performance are included.

At European level, a larger consensus is reached about the different areas covered by the Municipal Building Regulation. As indicated in [2], the following four main areas are present in most cases, with a different degree of in-depth analysis: ecological quality; economic quality; social quality and functional quality.

The area to which greater attention is paid is ecological quality with particular reference to the energy related parameters. All countries introduce indications about the minimum energy performance of buildings, about the use of renewable energy sources and in general the performances of the building envelopes (e.g., minimum thermal transmittance and air sealing of the building values). This is due to the fact that these features else than being clearly ruled by the European Directives, are also easy to be quantified and thus can be easily checked by local administrations for issueing permits or giving incentives.

Also the attention towards the use of low environmental impact building materials, such as recycled, is a shared issue.

\footnotetext{
${ }^{1}$ The term 'building regulations' is used differently in the member states. For some it refers to the technical building regulations on construction works or construction products, as laid down in many countries in Building Codes. For others it has a more broad meaning, also including local government planning and zoning regulations, environmental regulations, regulations for safe working conditions etc. [2]. In this work we refer to all the legally municipal binding provision imposing mandatory or semi-mandatory requirements on the planning, the design, the execution, the maintenance and the use of construction works.
} 
The aspects dealt with very diversified approaches are those that are not backed up by European Directives and that are ruled at local level. These concern indications for the economic and environmental optimization of the building productive process, as well as guidelines for the minimization of the use of resources in the building yard (energy and water), for the minimization of waste production and valorization of local economy. Other issues accounted for are the quality of the designed environment, thermal and acoustic comfort, lighting and access to green spaces.

Most countries have issued Building Regulation guidelines at national level, leaving the implementation details and and enforcement to the local decision level [2].

Notwithstanding the fact that Italy has transposed the European Directives on energy efficiency, a big effort has then been asked to support the implementation at local level. The distributed transposition on the Italian territory of such regulatory framework, at local level, is characterized by a delay, as compared to the european average [1], for what concerns the real implementation of best practices for energy efficiency in buildings.

In Italy, the regulation of urban-historical aspects is worked out at Municipal level. Such ruling system is traditionally connected to two complementary planning tools: the Technical Implementation Norms of the Municipal General Urban Planning and the Municipal Building Regulation. It is right at this level that a substantial lack of updating of the regulatory and planning tools can be found, especially in the energy sector [3].

Such condition, especially in small urban centers, is caused by the lack of sensitivity towards the issue of energy efficiency from municipal administrations. Such condition is even worsened by the absence of specific competences in the public administration staff and by the necessity to face the emergencies concerning the primary services to citizens such as the waste collection, mobility and vehicular congestion, hydrogeological risk, etc. This context leaves the update of the building techniques according to energy efficiency rules to the sensitiviy and the knowledge of the single operators in the different areas, giving rise to large violations even of the national regulatory framework. This happens mostly in small centers and in southern Italy.

Therefore it is clear that in Italy, like in other European countries that show a retardation on the issues of energy efficiency in buildings, it is mandatory to create tools to fruitfully address local administrators choices and policies towards the urban regeneration, trying to compensate the gap between Euroepan policies and local choices and implementations.

The new urban quality requires the integration of planning and design levels in the aim of attaining a real change even at local level.

The Municipal Building Regulation, MBR, referring to the building practice, seems to be one of the most effective technical-operational tools to embrace the integration of the two levels. It is indeed a fundamental turning point of the building process, since in it technical and procedural aspects converge. The MBR is strongly connected to the territory and is often defined through a 'bottom-up' approach, accounting for the critical aspects and the features of the ruled context, but at the same time it adapts to the rush towards sustainable development of cities that EU and then Member States are strongly supporting. 


\section{Sustainable Building Regulations in Italy}

In Italy, below the national legislation level, the regional level law regulates some specific subjects. However, in some topics, national and regional levels are concurrent, such as in the case of urban planning, for which both national and regional policy levels can issue regulations. Within the planning process, the MBR integrates building aspects with energy efficiency measures. Cross competences of different actors in the fields of urban planning, building and energy sectors must be accounted for in the definition of MBR. Participation and sharing in the frame of the national framework are crucial aspects of the process of definition of the MBR.

The resulting document must be shared among stakeholders in the building sector (designers and companies) and must be applicable both at administrative and at technical levels.

In Italy, in the last years, a number of regional laws centered on energy efficiency have been issued in the aim of filling the regulatory gap that for years has characterised the italian national legislation in the field of energy efficiency. Many regions have indeed autonomusly defined methodologies, limits, energy efficiency criteria to be applied to new buildings or restructurings (e.g., Lombardia Region).

In most regions of Italy, the urban planning and building regulations are driven by 'regional guidelines for sustainable Municipal Building Regulations', in this way the municipal policy level can integrate shared rules for the revision of existing MBR.

In some cases the municipal administrations have formulated an Energy Annex to the existing MBR, entirely following the performance parameters indicated in the guidelines. The cited annex is an efficient tool to rule the building transformations following environmental compatibility and energy efficiency criteria, since the formulation of an 'Annex' is more flexible, allowing an easy and continuous updating of the performance and technological parameters, giving rise to sensible regulatory and market changes in continuous evolution.

On the other hand, the Energy Annex allows to keep, inside the main MBR document, all the features concerning general urban planning (like minimum/maximum distance requirements, interventions classification, disabled accessibility, etc), that are not strictly part of the energy issues.

A Legambiente ${ }^{2}$ report [3], about the contents of the major Italian MBR, shows that a mixed performance based/prescriptive approach is the preferred choice in Italy. The most common structure includes operational rules concerning performances or specific requirements, that can be either mandatory or voluntary and that are distinguished by category of building intervention and by subject area concern the main fields of action of sustainable building practice:

${ }^{2}$ Legambiente is the most widespread italian environmental organization in the country. It is recognized by the Ministry for the Environment, Land and Sea as an association of environmental interest and it is part of the European Office of the Environment and of the International Union for Conservation of Nature. 
- reduction of energy consumption. Interventions that reduce the energy consumption in dwelling, increasing the thermal insulation of buildings and enhancing the passive solar gains and efficiency in end uses;

- renewable sources of energy. Use and integrate in buildings the production of electrical energy, heating and cooling by renewable systems;

- the water cycle. Reduce water consumption needs in dwellings through recovery, purification, reuse for compatible uses also increasing the permeability of the soil.

In the most complete type of Energy Annex, each article is complemented by a qualitative description of the benefits that the provided actions are causing and the actions of verification and control that the City Council will put in place to verify the compliance of the project to the requirements. These contents, are better specified, for mandatory items.

Only in a few cases, the energy aspects of buildings are included in a more complex regulatory document. Infact, with the enactment of specific regional laws, in some italian regions (e.g., Emilia Romagna and Tuscany), the Building Regulations has taken on a new role, governing all possible interventions on the existing city, connecting the issues of sustainable building with ones of urban spaces and extending the view from a single building to public space and the neighborhood. The document then becomes a full-fledged Urban Building Regulations, with rules and performance limits, schedules and tables indicative of the organization of open spaces and uses, as well as the design criteria of the built-up area, the city's historic and rural areas, then going to define general guidelines for designers (e.g., the MBR of Bologna [4], in force since May 2009).

In these cases, the document assumes a more generalized performance-based character, characterized by the identification of the goals to be achieved without a pre-set and pre-figured solution to obtain the desired result. The Administration on its side must acquire the evaluation of interventions, with the assumption of responsibility to judge what is coherent with the MBR and what is not.

This performance based approach is applied in Italy only in municipalities that showed, for a long time, an increased focus on energy planning and in which there is a greater awareness from the stakeholders to the overall aspects of urban planning.

In other regions, however, especially those in southern Italy, we are witnessing a deadlock in terms of regulatory efficiency, therefore the contents of the MBR shall continue to be confined to regulate with binding rules and prescriptive technical aspects of buildings and their appurtenances according to a logic that does not refer to the performance of what is the object of regulation, but simply put numerical parameters over the technical-aesthetic, hygienic and health-related features, safety and livability of the property, without taking into account factors such as living comfort and energy consumption.

Below (Fig. 2) some data from the ONRE Report 2013 (National Observatory Building Regulations) [5], led by Cresme ${ }^{3}$ and Legambiente, are reported. They relate to the distribution of Italian municipalities that have put in place to date a revision of

\footnotetext{
${ }^{3}$ Italian Centre for Social and Economic Research of the market for the building and the land.
} 


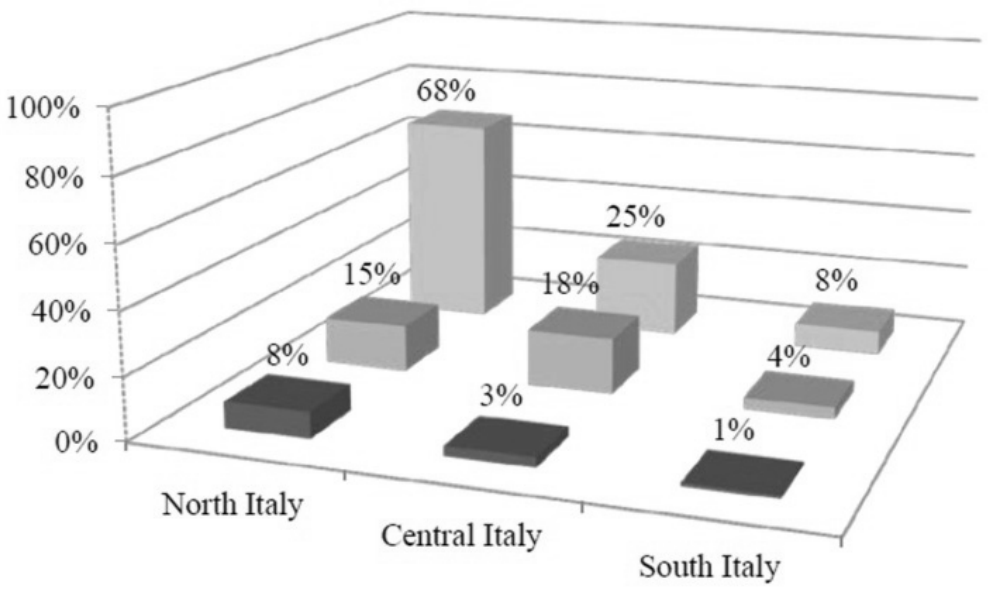

Values respect the overall number of Italian municipalities (8.092)

-Values respect the overall number of Italian municipalities identified by geographical zone (North, Central and South Italy)

Values respect the overall number of municipalities that have revised the MBR until $2013(1.003)$

Fig. 2. Percentage of number of municipalities per geographical zone, that have revised the MBR until 2013 in Italy, respect to: overall Italian municipalities, Italian municipalities per geographical zone and overall Italian municipalities that have revised the MBR until 2013 (Source: [5])

its MBR. The municipalities that were engaged in the review and reformulation of the BR following energy-environmental issues, in Italy were about 1003 (12\% of the overall Italian municipalities) in 2013, and were located in big cities and small towns. It is interesting to note that this change in Italy is recent (only $14 \%$ of the total of the Municipal Building Regulations is prior to 2006) and how, despite the geographical distribution shows the presence of at least one sustainable MBR in all regions of the country, the largest concentration is in the Centre-North. The latter are also the regions that have, first than others, in Italy enacted specific laws for energy efficiency and energy, thus defining a clear policy direction that allowed municipal administrations to start their journey towards sustainability in construction.

A significant element that may largely explain the high concentration of these innovative tools in the north of Italy is also linked with the climatic conditions of these regions and the resulting know-how in this field.

Italian territory from a climatic point of view is very different. A complete overview of this is given by a Italian Presidential Decree [6] that splits the country into Climate Zones ${ }^{4}$ which are distinguished based on Degree-Day values (decreasing from $\mathrm{F}$ to A zone). The value of Degree-Days of a location, depends on the mean daily external temperature, this is the reason for which locations that are located in the same region can have a different number of Degree-Day. Infact, the daily average

${ }^{4}$ The Climate Zone is expressed in degree days that express the sum, extended to all days of an annual period conventional heating, of only the positive differences between the daily temperature, conventionally fixed at $20^{\circ} \mathrm{C}$, and the average outside temperature daily. 


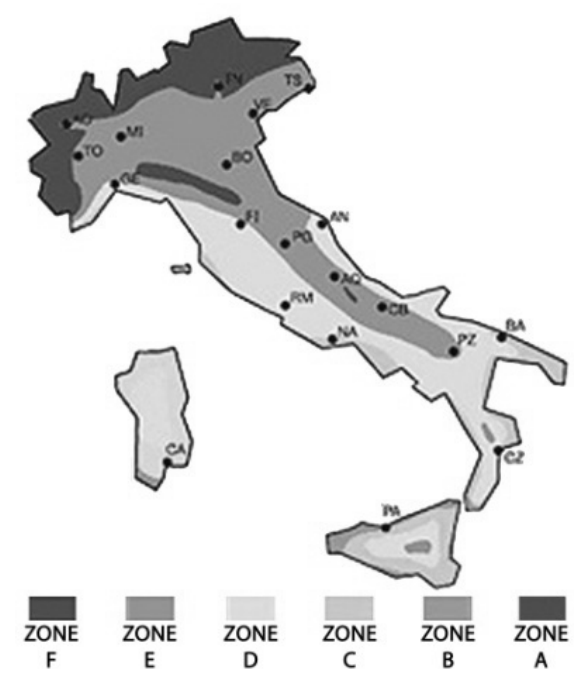

Fig. 3. Classification of the Italian country in Climatic Zones, according to the Italian Presidential Decree n.412/1993 (Source: [6])

outdoor temperature is influenced by geographical factors, primarily the height above sea level but also protection from the prevailing winds, proximity to the sea or lakes, etc.). Figure 3 illustrates this classification.

The regions located on the centre-north of Italy (F, E, D Zones) have a higher value of degree days, and then have an external temperature lower during the winter period, the opposite occurs, however, in the major part of the municipalities in the southern regions ( $\mathrm{C}, \mathrm{B}, \mathrm{A}$ Zones).

If the Sustainable Italian MBR are analyzed [5], it can be seen how the key issues addressed are almost the same in all regions and are based on the one hand on the indications of the national legislation of the sector, very often expanding the contents and including improved performance indications, on the other hand on the most wellknown parameters of sustainable building.

As previously mentioned, the largest energy consumption in Italy, in the field of residential building, are due to heating. The most common solutions placed within the Municipal Building Regulations in Italy, aim to achieve a reduction in consumption in heating and generally refer to consolidated knowledge about the thermo-physical behavior of buildings. The behavior of buildings in cold climates, and the subsequent identification of the most suitable solutions to be implemented to achieve high performance buildings, is a subject which, for many years, has been treated in the literature and which has been widely discussed by the most well known certification bodies in the energy field in Italy and abroad, i.e., the Agency for Energy Klima House Alto Adige (Bolzano, Italy) and the Passivhaus Institut (Darmstadt, Germany), which are joined from operating in cold climates.

The following figure (Fig.4) is an analysis of the Cresme and Legambiente [5] concerning the parameters considered versus the number of MBR in which they are inserted. As it can be noted, the thermal insulation together with the obligation to 


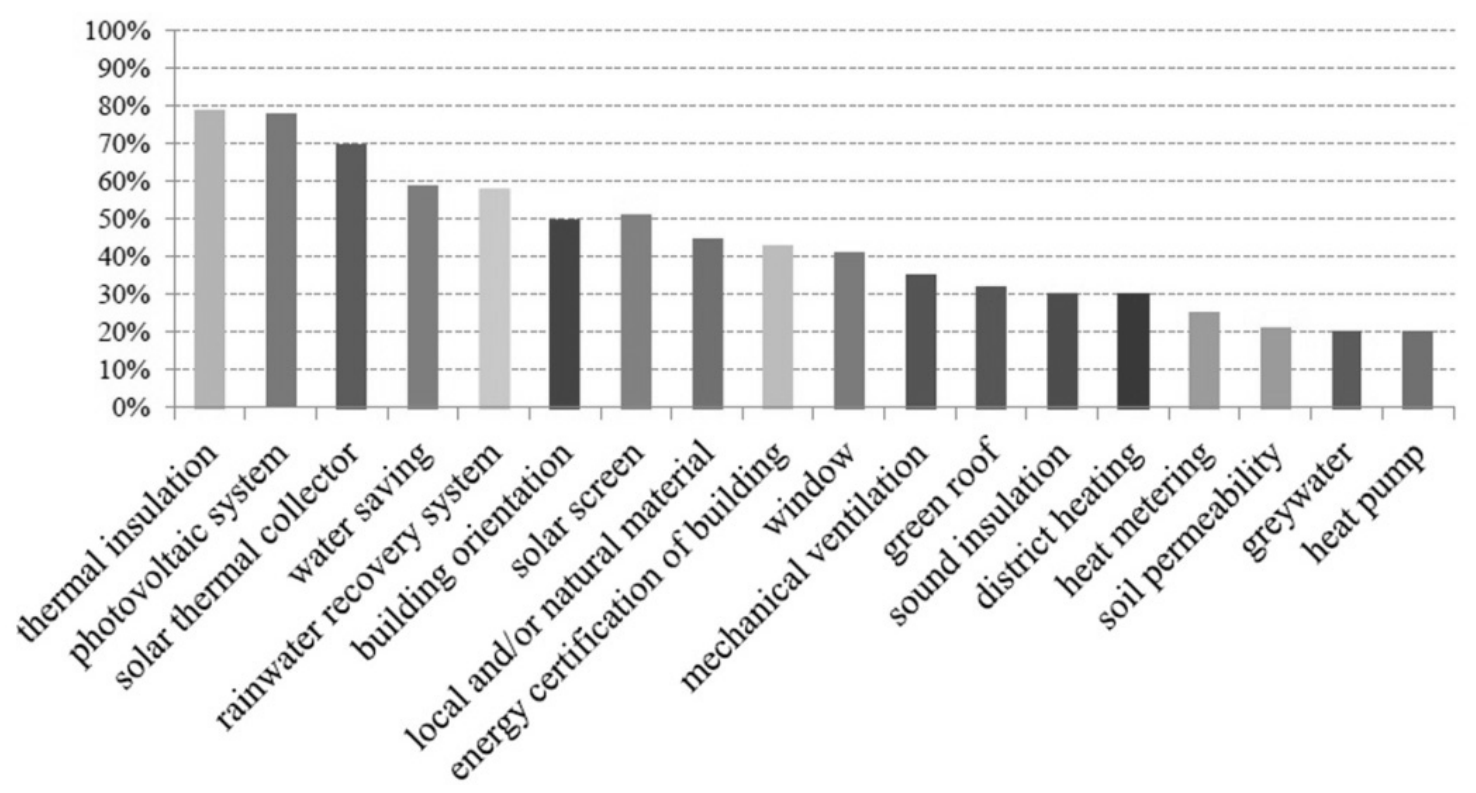

Fig. 4. Percentage values of the most considered parameters entered in the revised MBR in Italy until 2013 (Source: [5])

install photovoltaic panels and solar thermal systems are the most commonly adopted measures, indeed these measures are dictated as mandatory by Decree n. 28/2011 ${ }^{5}$.

The fundamental difference between the various regulations is how these parameters are introduced into the regulatory document, this is essentially function of the climatic situation and territory, present in the municipal context. The indications are varied based on the place to which they relate. The obligations may then take several minimum requirements, however, acknowledging at least the minimum required by the regulations in force, in reference both to the use of renewable energy systems, as well as to the transmittance of the elements of the coating or the performance of heat generators.

Despite, for some years, the European Community shall initiate research projects with the aim of studying and promoting the most suitable methods to limit the summer thermal loads in buildings, mainly through passive solutions (e.g., Keep Cool project $^{6}$, [7] and Passive-On project $\left.{ }^{7}[8,9]\right)$. Infact demand for cooling energy is expected to rise dramatically in Europe in the coming years [7] and more in some countries in the Mediterranean area.

5 The Decree n. 28 of May 3rd, 2011 transposes into the Italian legislation the Directive 2009/28/EC provisions on the promotion of the use of energy from renewable sources.

${ }^{6}$ The aim of this project (2005-2007) was to propose intelligent ways of getting passive cooling to penetrate the market and to establish a new definition of sustainable summer comfort.

${ }^{7}$ Passive-On is a completed research and dissemination project (2005-2007) which was funded within the Intelligent Energy for Europe SAVE programme. The project worked to promote Passive Houses and the Passivhaus Standard in warm climates. 
For this reason, with the support of the most innovative MBR of Italy and of the general indications of the studies mentioned above, it was decided to present, in paragraph 3, the structure of a municipal building regulation for the municipalities in Sicily as an example of the Southern European area.

\section{Contents of a Sample Energy Annex}

As mentioned above, the most common way to revisit the MBR in Italy in order to include energy efficiency measures, is to structure the content relating to sustainable building within topic areas containing mixed performance/prescriptive based requirements, both mandatory or optional. The thematic areas identified are designed to group the main systems that can contribute to reducing the energy consumption of existing building and of new building.

Even if the proposed structure, in its general content, is applicable to all the regions in Italy and their climatic zones, it was decided, due to more scarce presence of sustainable MBR in southern Italy, to propose in the following section an application referred to mild climates. The example is that of the municipalities in the region of Sicily.

The Region of Sicily is, from a climatic point of view, the most varied region of Italy. As shown in Figure 3, it present almost all the Climatic Zones of Italy (although the area are mainly the B, C and D Zones); for this reason, the development of regional guidelines for the drafting of sustainable MBR is difficult to standardize. This is probably also the reason why the sustainable MBR in Sicily are very few. Moreover from the analysis of the energy consumption in buildings of the Sicilian region, not surprising that the peak comes during the summer season in the hours of major irradiation. Such data can be essentially connected to the climate features of Sicily that comprises different climatic zones, but is characterized by very hot summers in all the region. So in climatic conditions like this, parameters such as solar screens, massive construction of building envelopes, green or ventilated roofs, passive cooling systems, solar thermal system, permeability of the soil, acquire more importance than others that are more commonly addressed in building regulations in climates of central and northern Italy (Fig.4).

In Table.1 a draft of Energy Annex to the MBR is reported. For sake of completeness, this contains the major topics related to the definition of an Energy Annex, including those, more general, that are related to parameters shared by the municipalities belonging to all regions of Italy without distinction of climate zone. The areas covered are:

Area 1. Environmental sustainability and enhancement of the context

Area 2. Energy performance of building envelope

Area 3: Energy performance of technical systems

Area 4. Renewable energy sources 
Table 1. Areas and contents of the energy annex to the municipal building regulation for a mild climate city

\begin{tabular}{|c|c|c|}
\hline $\begin{array}{l}\text { The- } \\
\text { matic } \\
\text { areas }\end{array}$ & Articles & Requirements \\
\hline \multirow{6}{*}{$\begin{array}{c}\text { Area } \\
1\end{array}$} & $\begin{array}{l}\text { Art.1 Building } \\
\text { orientation }\end{array}$ & $\begin{array}{l}\text { The layout solutions for new building and open spaces will be designed taking } \\
\text { into account the apparent path of the sun and prevailing winds, favouring } \\
\text { compact forms and conditions of exposure and orientation of buildings such } \\
\text { as to maximize heat gains in winter and reduce them during the summer } \\
\text { period. Arrange the windows of larger surface area and the rooms in which } \\
\text { the majority of the inhabitants lives, in the south-east, south and south-west } \\
\text { directions to bring in natural light, taking care to set the required screening } \\
\text { elements at least } 70 \% \text { of the glass surface so as to allow the control of solar } \\
\text { radiation in the summer period. If these measures are not adopted, design } \\
\text { solutions that will reduce by at least } 20 \% \text { of the energy needs of primary } \\
\text { energy will have to be implemented. }[9,10,11]\end{array}$ \\
\hline & $\begin{array}{l}\text { Art.2 Natural } \\
\text { lighting }\end{array}$ & $\begin{array}{l}\text { In order to ensure the optical-visual wellbeing of the occupants, the natural } \\
\text { light into the building should be used at its best. Artificial lighting should be } \\
\text { integrated by balancing the visual needs with energy savings. If the planimet- } \\
\text { ric shape of new buildings does not have sufficient land to direct uptake of } \\
\text { natural light, this can be ensured by means of zenithal lighting systems, this } \\
\text { rule must be in accordance with the hygienic rules of the City [11]. }\end{array}$ \\
\hline & $\begin{array}{l}\text { Art.3 External } \\
\text { microclimate } \\
\text { control }\end{array}$ & $\begin{array}{l}\text { In order to limit the rise of local temperatures in densely built areas (urban } \\
\text { heat island) for the benefit of the natural cooling in the summer, the trees } \\
\text { around the building will be designed like protective elements of the fronts } \\
\text { exposed to the winter wind and direct radiation in the summer. For external } \\
\text { paving will be used materials with high reflectivity (cool material) such as } \\
\text { turf, light stone, wood, or possibly draining pavement [11]. }\end{array}$ \\
\hline & $\begin{array}{l}\text { Art.4 Usage of } \\
\text { arboreal types }\end{array}$ & $\begin{array}{l}\text { In new building constructions and existing buildings, if it is possible, to limit } \\
\text { the thermal load in summer and preserve the soil permeability, at least } 20 \% \\
\text { [11] of the area of the project is to be used as green space, with the planting of } \\
\text { trees with large crown or suitable to create shading in the external walls of } \\
\text { buildings exposed to the east, west and south. For the same reason is to prefer } \\
\text { the achievement of green roofs. It is advisable to design the most suitable } \\
\text { composition of vegetation, preferring the use of native plant species. }\end{array}$ \\
\hline & $\begin{array}{l}\text { Art.5 Water } \\
\text { saving }\end{array}$ & $\begin{array}{l}\text { In order to reduce the consumption of safe water, in all cases of new building } \\
\text { and building renovations, is important to provide the mandatory installation of } \\
\text { suitable devices to limit the use of it. Install individual meters of safe water } \\
\text { per each housing, as well as provide filtration and storage systems of rain- } \\
\text { water from the roofs and possibly even wastewater to be sent for recovery for } \\
\text { compatible uses inside or outside of the building }[12,13] \text {. }\end{array}$ \\
\hline & $\begin{array}{c}\text { Art.6 Usage of } \\
\text { eco-friendly } \\
\text { and recycled } \\
\text { materials }\end{array}$ & $\begin{array}{l}\text { To build is recommended to use natural or recycled materials, which require } \\
\text { low embodied energy and low environmental impact throughout their entire } \\
\text { life cycle. The use of sustainable materials, however, must ensure compliance } \\
\text { with the regulations regarding energy efficiency, the acoustic quality and } \\
\text { safety of buildings. The use of locally produced materials must to be duly } \\
\text { certified and also incentivize by the municipality [11,12]. }\end{array}$ \\
\hline $\begin{array}{c}\text { Area } \\
2\end{array}$ & $\begin{array}{l}\text { Art.7 Acoustic } \\
\text { pollution } \\
\text { control }\end{array}$ & $\begin{array}{l}\text { In new building constructions or major building renovations, the exposure to } \\
\text { noise sources (e.g., external noise, noise from other properties, from the } \\
\text { shared areas, the sounds of footsteps and plants) must be minimized, consis- } \\
\text { tently with the context and constraints. Consider the possible use of specific } \\
\text { architectural solutions that limit the exposure of the receptors to noise pollu- } \\
\text { tion, such as, articulation of the massing of the building, so as to achieve } \\
\text { effective shielding against sound sources; use of large balconies or loggias } \\
\text { with parapets and full use of sound-absorbing materials on ceilings; use of } \\
\text { glazed elements with acoustic insulation properties and use of trees [10,11] }\end{array}$ \\
\hline
\end{tabular}


Table 1. (continued)

\begin{tabular}{|c|c|}
\hline $\begin{array}{l}\text { Art. } 8 \text { Ratio } \\
\text { between dis- } \\
\text { persion surface } \\
\text { and controlled } \\
\text { temperature } \\
\text { volume }\end{array}$ & $\begin{array}{l}\text { For all categories of buildings for new construction and major renovations are } \\
\text { preferred limited ratios of } S / \mathrm{V} \text { (ratio of surface dispersants, flat and vertical to } \\
\text { the outside or to unheated spaces, with respect to the heated volume), obtain- } \\
\text { able through the use of regular and compact shapes. The increasing of the } \\
\text { surface area exposed to the outside, causes that the energy losses in the winter } \\
\text { and heat gains in summer, increase too. It must be considered, however, that a } \\
\text { more compact coating can make it difficult lighting and ventilation of internal } \\
\text { spaces, this element should be taken into account in the design jointly with the } \\
\text { necessity of limiting losses or heat gains [9], [14,15]. }\end{array}$ \\
\hline $\begin{array}{l}\text { Art. } 9^{8} \text { Ther- } \\
\text { mal insulation } \\
\text { of buildings } \\
\text { (building } \\
\text { features of } \\
\text { coatings- } \\
\text { winter) }\end{array}$ & $\begin{array}{l}\text { In order to enable a reduction in consumption of fossil fuels for heating in } \\
\text { winter, for new construction and major building renovations, it is appropriate } \\
\text { to reduce heat loss considering levels of thermal transmittance lower, if possi- } \\
\text { ble, for different parts of the building coating, both opaque (limited to walls } \\
\text { and roof [9]) and transparent. Improvements with respect to the parameters } \\
\text { imposed by the law will be rewarded by the administration (in Italy the decree } \\
\text { [16] fixed, among other things, the requirements of national minimum trans- } \\
\text { mittance of the envelope components and also the maximum primary energy } \\
\text { demand for winter heating). }\end{array}$ \\
\hline $\begin{array}{l}\text { Art. } 10^{9} \text { Ther- } \\
\text { mal insulation } \\
\text { of buildings } \\
\text { (building } \\
\text { features of } \\
\text { coatings- } \\
\text { summer) }\end{array}$ & $\begin{array}{l}\text { In order to ensure the passive control of thermal hygrometric comfort in } \\
\text { interior spaces, especially in the summer time, it is necessary that the struc- } \\
\text { tures of the building are able to attenuate and phase shift of the peak heat load } \\
\text { due to the impact of external sun. Furthermore it is necessary that they are } \\
\text { able to modulate the internal heat loads due, for example, to the presence of } \\
\text { people and to the effects induced by lighting and electrical equipment as well } \\
\text { as the infiltration of hot external air due to the opening of doors, as well as to } \\
\text { diffuse solar radiation through transparent closures. For this purpose, in new } \\
\text { constructions and major renovations, it is necessary to adopt building systems } \\
\text { that give to the external closures and walls, appropriate behaviour in terms of } \\
\text { thermal inertia, phase shift and attenuation of the thermal wave [17] or peri- } \\
\text { odic thermal transmittance complying at least with the minimum limits of the } \\
\text { Italian law [15]. In order to facilitate the night ventilation and the consequent }\end{array}$ \\
\hline
\end{tabular}

${ }^{8}$ A possible improvement of the transmittance of envelope components allow to reduce the heat winter losses also thanks to a highly air-sealed building envelope and to the elimination of thermal bridges. An increased of the air-sealing in the building envelope on the other hand, reduces the air changes of the building envelope, therefore, it may be required an additional ventilation system (such as for example a forced ventilation system with heat recovery from exhaust air). The energy required for winter heating is also reduced if the design includes the possibility to exploit the solar heat gains through the glass shutters or glass walls installed on the south, east, west oriented walls, this notation must be addressed, including appropriate screening systems possibly modular, that during the summer, which must be designed to minimize solar gains.

${ }^{9}$ The energy needs of the building in summer, are reduced if the solar earnings of the external surfaces are minimized thanks to a high thermal capacity (in Mediterranean climates especially if characterized by a high thermal capacity daily, about $15^{\circ} \mathrm{C}$, and then by an effective night ventilation, this allows to reduce the thermal load by summer cooling by 10 $40 \%$ compared to the case of enclosures with light same insulating performance [6], [18]) and also tank to the sun shadings (notations at art.11) or by suitable trees plantings (notations at art.4). A well-sealed and heavy structure is the ideal situation for the exploitation of the summer night cooling of the thermal mass of the building. During nighttime the air circulates through the building, using winds or natural air density gradients, or using a mechanical ventilation system (notations at art.17), setting partly free the building from the heat held by its mass. The greater or smaller efficiency of the system must however be verified with reference to the local climatic features of the site where the Municipality resides. 
Table 1. (continued)

\begin{tabular}{|c|c|c|}
\hline & & $\begin{array}{l}\text { cooling of the structure with high thermal capacity (especially in climates } \\
\text { characterized by high daily temperature range), in order to remove part of the } \\
\text { heat accumulated during the daylight hours, it is also recommended to evaluate } \\
\text { the use of devices for automatic opening of windows, or natural ventilation, as } \\
\text { well as the design of the interior spaces encouraging the movement of air, this } \\
\text { in order to keep the internal temperatures significantly below the external } \\
\text { environmental temperatures during the summer period [8,9]. In new buildings } \\
\text { and renovations, the thermal energy for cooling in summer must be between } \\
40-30 \mathrm{kWh} / \mathrm{m} 2^{10} \text { per year, this according to the directions of the law [15] }\end{array}$ \\
\hline & $\begin{array}{l}\text { Art.11 Shutters } \\
\text { performances } \\
\text { and shadings } \\
\text { control }\end{array}$ & $\begin{array}{l}\text { It is necessary to adopt integrated solutions that simultaneously monitor the } \\
\text { summer sunshine, favouring the winter sunshine and optimize the performance } \\
\text { of passive buildings. For this purpose, in new constructions, renovation or } \\
\text { repairs which affect even the replacement of windows, at least the limit value } \\
\text { of transmittance of the windows indicated by Italian law [16] must be ensured } \\
\text { (values improvements can be awarded by the municipality). It is also manda- } \\
\text { tory to use screening systems that will be congruent with the orientation of the } \\
\text { front on which they are installed (they may be vertical or horizontal, fixed or } \\
\text { mobile), so that in summer the sunny side of the transparent surfaces located on } \\
\text { the south, east and west, is equal to, or less than, 30\% [9,10]. Where this is not } \\
\text { possible for reasons of architectural significance the use of innovative tech- } \\
\text { nologies is required, such as the use of selective glazing [19]. }\end{array}$ \\
\hline & $\begin{array}{l}\text { Art.12 Roofs } \\
\text { performances }\end{array}$ & $\begin{array}{l}\text { For new buildings and those subject to demolition and reconstruction in total } \\
\text { restructuring, for the extraordinary maintenance of continuous and discontinu- } \\
\text { ous roofs with complete revision of the mantle, in the case where the roof is in } \\
\text { direct contact with rooms that are accessible and the roof is a pitch roof (for } \\
\text { example under the roof, attic, etc.), ventilated solutions or equivalent will be } \\
\text { preferred, to reduce the surface temperatures of the summer covers and the } \\
\text { amount of energy transferred inside the building, in order to reduce the 'heat } \\
\text { island effect', it will be preferable to use light coloured surfaces, coatings with } \\
\text { high reflectivity or construction of green roofs [9], [11]. }\end{array}$ \\
\hline & $\begin{array}{c}\text { Art.13 Use of } \\
\text { passive cooling } \\
\text { measures }\end{array}$ & $\begin{array}{l}\text { In new constructions and major renovations in order to promote energy con- } \\
\text { servation, ensuring the air natural conditioning in summer and improving } \\
\text { wellbeing in the interior spaces, where possible, solutions that enable to take } \\
\text { advantage of the temperature difference between opposite sides creating } \\
\text { ventilation loop must be implemented (such as the construction of windows } \\
\text { on the north and south) as well as to provide an organization of interior spaces } \\
\text { which does not create an obstacle to the flow of air directed through the open- } \\
\text { ings from the windward side to the leeward ones. Ventilation must be highest } \\
\text { during the day, during the summer season, in the areas most frequently used } \\
\text { by the inhabitants and the airflow should be up to the walls, those that store } \\
\text { the most heat. If the intervention makes it possible the use of water reservoirs } \\
\text { near the openings of the building, the cooling water potential in the evapora- } \\
\text { tion must be exploited [8,9]. }\end{array}$ \\
\hline $\begin{array}{c}\text { Are } \\
3\end{array}$ & $\begin{array}{l}\text { Art.14 High } \\
\text { performance } \\
\text { heat generation } \\
\text { systems, ther- } \\
\text { mal centralized } \\
\text { plants and } \\
\text { metering } \\
\text { systems }\end{array}$ & $\begin{array}{l}\text { In new construction and major renovations to the entire heating plant is neces- } \\
\text { sary to ensure the highest possible level of average seasonal efficiency of the } \\
\text { heating system (levels greater than those imposed by law [15] will be pro- } \\
\text { moted by the municipality) using centralized systems, in buildings with mul- } \\
\text { tiple dwellings, it is required the use of heating plants with high efficiency } \\
\text { (condensing boilers, micro CHP plants, heat pumps, compression and absorp- } \\
\text { tion) that at least meets the performance requirements provided by law; mate- } \\
\text { rials, devices and products for the reduction of energy losses of the piping of } \\
\text { heating systems or for a better performance of the final spread of heat. Where } \\
\text { technically possible, it is mandatory the construction of facilities which permit } \\
\text { the accounting and thermoregulation of heat per housing unit and possibly } \\
\text { also for individual rooms or thermal zones [9]. }\end{array}$ \\
\hline
\end{tabular}

${ }^{10}$ It refers to the walkable area. 
Table 1. (continued)

\begin{tabular}{|c|c|c|}
\hline & $\begin{array}{l}\text { Art. } 15 \text { Ther- } \\
\text { mal regulation } \\
\text { systems }\end{array}$ & $\begin{array}{l}\text { For the purposes of thermo hygrometric comfort and reducing energy con- } \\
\text { sumption, adequate levels of air and surface temperature in the interior spaces } \\
\text { of the buildings should be guaranteed. Subject to any exceptions provided by } \\
\text { law, during the period of operation of the heating the indoor air temperature } \\
\text { (Ti) for the closed spaces for principal and secondary activities should be } \\
18^{\circ} \mathrm{C}<\mathrm{Ti}<22^{\circ} \mathrm{C} \text {; it must also not show, if measured along the vertical axis } \\
\text { (ideal straight floor ceiling), differences of more than } 2^{\circ} \mathrm{C} \text {. The operating } \\
\text { temperature (Top) for residential uses should be around } 20^{\circ} \mathrm{C} \text { in winter and } \\
\text { below } 26^{\circ} \mathrm{C} \text { in summer [9], [15]. }\end{array}$ \\
\hline & $\begin{array}{l}\text { Art.16 Low } \\
\text { temperature } \\
\text { systems }\end{array}$ & $\begin{array}{l}\text { In order to optimize the use of high efficiency generators for heating during } \\
\text { winter is recommended the use of distribution systems at low temperature } \\
\text { (like radiant panels, embedded in the floors or in walls, or fan coils). The } \\
\text { radiating systems can also be used as air conditioning terminals provided that } \\
\text { devices, for the control of relative humidity, are added in the plant }{ }^{11} \text {. The } \\
\text { installation of radiant floor or ceiling panels in existing buildings must not } \\
\text { compromise the achievement of the minimum heights of the premises laid } \\
\text { down by the legislation in force [11], [21]. }\end{array}$ \\
\hline & $\begin{array}{l}\text { Art. } 17 \mathrm{Me}- \\
\text { chanical venti- } \\
\text { lation systems }\end{array}$ & $\begin{array}{l}\text { In order to ensure satisfactory conditions of hygiene, health and environ- } \\
\text { mental well being, ventilation of internal spaces is an essential condition. } \\
\text { Where it is not effective natural ventilation system, and mandatory in build- } \\
\text { ings for public use, it is necessary to install mechanical ventilation devices } \\
\text { with heat recovery. That allow to control the relative humidity, mitigate the } \\
\text { effects of steam condensation and prevent the formation of microbial colo- } \\
\text { nies, this allows to limit the energy needs [9], [15], [20]. }\end{array}$ \\
\hline $\begin{array}{c}\text { Area } \\
4\end{array}$ & $\begin{array}{l}\text { Art.18 Solar } \\
\text { thermal sys- } \\
\text { tems }\end{array}$ & $\begin{array}{l}\text { For new buildings, and existing buildings subjected to demolition and recon- } \\
\text { struction in maintenance, and for those subject to full re-structuring of the } \\
\text { elements making up the building envelope it is mandatory to cover, through } \\
\text { the use of energy produced from renewable sources, at least } 50 \% \text { of the } \\
\text { demand for domestic hot water [22], this requirement has to be met on a } \\
\text { priority basis through solar thermal systems. It is preferable that the solar } \\
\text { collectors are installed on roofs and façades exposed to the South, Southeast, } \\
\text { Southwest, East and West, without prejudice to morphological elements, } \\
\text { urban planning, and landscape protection. In the case of flat roofs the panels } \\
\text { can be installed with the inclination considered optimal, although it is prefer- } \\
\text { able that they are not visible from the road below, and it is mandatory that the } \\
\text { system be achieved by ensuring compliance with the formal consistency of } \\
\text { the building and minimizing the visual impact on buildings. It is allowed to } \\
\text { install panels on facades and coating of the building if and only if conceived } \\
\text { as elements that are functionally integrated into the facade. Where conditions } \\
\text { allow, the integration of this solar thermal system with the heating system of } \\
\text { the building will be prized by the administration. To connect the solar thermal } \\
\text { system to the individual users appropriate rooms must be accounted for in the } \\
\text { building. } \\
\text { If the location of the building makes neither it nor possible the use of solar } \\
\text { thermal panels an alternative renewable source will have to be found for the } \\
\text { complete satisfaction of the obligation [14], [22]. } \\
\text { In new and existing buildings (public and private) in which it is expected that } \\
\text { the complete replacement of the cooling system, it is possible to consider the } \\
\text { design and installation of solar cooling (associated with solar thermal cooling } \\
\text { absorption machine) in order to achieve renewable energy based cooling } \\
\text { systems [23]. }\end{array}$ \\
\hline
\end{tabular}

${ }^{11}$ This is to limit the risk of condensation on the cold surface and to obtain a condition of comfort. As recommended by the UNI EN 7730, the relative humidity should not exceed 60 to $65 \%$ to ensure a feeling of comfort. 
Table 1. (continued)

\begin{tabular}{|c|c|l|}
\hline $\begin{array}{c}\text { Art.19 Renew- } \\
\text { able energy } \\
\text { sources for } \\
\text { electrical } \\
\text { energy genera- } \\
\text { tion }\end{array}$ & $\begin{array}{l}\text { In the case of new buildings or buildings undergoing major renovation it is } \\
\text { required to install an renewable electric power system, at least equal to that } \\
\text { required by law [22] (solutions that allow an almost total coverage of the } \\
\text { needs of the building through these facilities will be rewarded by the local } \\
\text { administration). Given the favorable conditions of average solar radiation are } \\
\text { preferred photovoltaic systems, for the use of photovoltaic systems apply the } \\
\text { same indications of architectural integration mentioned in the previous article. } \\
\text { The projects of new buildings and major renovations of existing buildings } \\
\text { ensuring a coverage of the consumption of heat and electricity for cooling in } \\
\text { excess of at least 30\% compared with the minimum requirements set out in } \\
\text { [22], will be prized, upon issuance of the building licence, with a bonus of 5\% } \\
\text { volume. It is permitted the installation of systems using geothermal, hydroe- } \\
\text { lectric or wind power as long as they conform to the standards in force within } \\
\text { urban planning and landscape of the town. }\end{array}$ \\
\hline $\begin{array}{c}\text { Art.20 Electri- } \\
\text { cal infrastruc- } \\
\text { tures for } \\
\text { electric vehi- } \\
\text { cles recharging }\end{array}$ & $\begin{array}{l}\text { It is mandatory for new residential buildings or for residential buildings going } \\
\text { under major renovation with surface area not greater than 500 m2 the installa- } \\
\text { tion of or predisposition for a charging infrastructure for electric vehicles } \\
\text { likely to allow the connection of a car in each covered or uncovered parking } \\
\text { space, and in each parking lot within a closed area, whether related to the } \\
\text { building or not. Infrastructure, including private, intended for charging vehi- } \\
\text { cles powered by electricity are primary infrastructure works realized in the } \\
\text { entire municipality are exempted from construction taxes }{ }^{12} .\end{array}$ \\
\hline
\end{tabular}

The table above is indicative of the contents that can be inserted in the energy Annex to the MBR for a municipal authority in the regions of central and southern Italy.

The more detailed practical and operational indications will provide a tool which will become as more effective, as more the indications can be easily translated into effective actions. It is the task of the Administration, on the basis of climatic parameters and urban context, to rule and specify more technical specifications.

\section{Conclusions}

In this paper the issue of energy efficiency in buildings is treated considering one of the most important implementation tools: the Municipal Building Regulation. After a comprehensive state of the art on the existing best practices in Europe a focus in Italy is proposed and the structure of the energy annex for sustainable Building Regulations in proposed. The application is devoted to southern Italy, proposing measures that are well designed for hot and mild climates.

${ }^{12}$ Notation introduced in accordance with the instructions contained in the Italian National Plan of Infrastructure for recharging vehicles powered by electricity, in relation to the voice of the Town Planning Review: incentives and obligations. 


\section{References}

1. Unità Tecnica Efficienza Energetica dell'ENEA: Rapporto Annuale Efficienza Energetica. In: RAEE 2011. Executive Summary, Rome, Italy (2012)

2. PRC Bouwcentrum International, Delft University of Technology Bodegraven: The lead market initiative and sustainable construction: lot 1, screening of national building regulations. Final report, Delft, Netherlands (2011)

3. Legambiente: Il Regolamento edilizio d'Italia (2012)

4. Comune di Bologna: Regolamento Urbanistico Edilizio della città di Bologna. Bologna, Italy (2009)

5. Cresme Ricerche, Legambiente: L'Innovazione Energetica in Edilizia - I regolamenti edilizi comunali e lo scenario dell'innovazione energetica e ambientale in Italia. Rapporto ONRE (2013)

6. Italian Presidential Decree n.412/1993: Regolamento recante norme per la progettazione, l'installazione, l'esercizio e la manutenzione degli impianti termici degli edifici ai fini del contenimento dei consumi di energia (1993)

7. Varga, M., Bangens, L., Cavelius, R., et al.: Service Buildings Keep Cool: Promotion of sustainable cooling in the service building sector. Final report, Austrian Energy Agency, Vienna (2007)

8. Ford, B., Schiano-Phan, R., Zhongcheng, D.: The Passivhaus Standard in European warm climates: design guidelines for comfortable low energy homes - Part 3: comfort, climate and passive strategies. Part 3 report of Passive-On Project (2007)

9. Pagliano, L., Carlucci, S., Toppi, T., Zangheri, P.: Passivhaus per il sud dell'Europa-Linee guida per la progettazione. Rockwool guide, 'Passive-On' IEE Project, Milan, Italy (2009)

10. Comune di Bari: Nuovo Regolamento edilizio della città di Bari. Bari, Italy (2012)

11. Infoenergia, Dipartimento BEST Politecnico di Milano: Definizione di regole per strumenti urbanistici orientati alla valorizzazione energetica ed ambientale - Linee Guida, provincia di Monza Brianza. Italy (2012)

12. Sicilian Decree n. 18/Gab (Decreto attuativo, R.L n.6 del 23 marzo 2010): Caratteristiche tecnico costruttive per gli interventi di bioedilizia nei casi di demolizione e ricostruzione

13. Comune di Monterotondo: Norme per la sostenibilità ambientale allegate al regolamento edilizio. Monterotondo, Province of Rome, Italy (2009)

14. Italian Legislative Decree n.192/2005: Attuazione della direttiva 2002/91/CE relativa al rendimento energetico nell' edilizia (2005)

15. Italian Presidential Decree n.59/2009: Regolamento di attuazione dell'articolo 4, comma 1, lettere a) e b), del decreto legislativo 19 agosto 2005, n. 192, concernente attuazione della direttiva 2002/91/CE sul rendimento energetico in edilizia (2009)

16. Italian Legislative Decree n.311/2006 Disposizioni correttive ed integrative al decreto legislativo 19 agosto 2005, n. 192, recante attuazione della direttiva 2002/91/CE, relativa al rendimento energetico nell' edilizia (2006)

17. UNI EN ISO 13786:2008: Prestazione termica dei componenti per edilizia - Caratteristiche termiche dinamiche (2008)

18. Zangheri, P., Pagliano, L., Carlucci, S.: Passive house optimization for Southern Italy based on the "New Passivhaus Standard". In: ECEEE Summer Study: act! Innovate! Deliver! Reducing Energy Demand Sustainably, pp. 1643-1648. La Colle sur Loup, France (2009)

19. Dama, A., Pagliano, L.: Vetri ad alte prestazioni energetiche. In: Il Progetto Sostenibile, Italy, vol. 2005, pp. 60-65 (2005) 
20. UNI EN 15251: Criteri per la progettazione dell'ambiente interno e per la valutazione della prestazione energetica degli edifici, in relazione alla qualità dell aria interna, all'ambiente termico, all'illuminazione e all'acustica (2008)

21. Initiative for Low Energy Training in Europe (ILETE): Labelling and Certification Guide. ILETE Report (2010)

22. Italian Legislative Decree n.28/2011: Attuazione della direttiva 2009/28/CE sulla promozione dell'uso dell'energia da fonti rinnovabili, recante modifica e successive abrogazione delle direttive 2001/77/CE e 2003/30/CE (2011)

23. Vaccaro, V.: The urban and environmental building code as implementation tool. In: Riva Sanseverino, E., Zizzo, G., Riva Sanseverino, R., Vaccaro, V. (eds.) Smart Rules for Smart Cities-Managing efficient cities in Euro-Mediterranean Countries, vol. 12, pp. 75-106. Springer for Innovation (2014) 